DOI 10.37882/2223-2974.2021.03.21

\title{
ПРОБЛЕМЫ ОБЩЕЙ ЧАСТИ УГОЛОВНОГО КОДЕКСА РФ, ОБНАРУЖЕННЫЕ ПРИ ИЗУЧЕНИИ СЛУЖЕБНОГО ПОДЛОГА (СУДЕЙСКОГО И ЗАКОНОДАТЕЛЬНОГО)
}

\section{PROBLEMS OF THE GENERAL PART OF THE CRIMINAL CODE OF THE RUSSIAN FEDERATION, FOUND IN THE STUDY OF OFFICIAL FORGERY (JUDICIAL AND LEGISLATIVE)}

A. Mitrofanov

Summary: In this article, on the basis of previous author's research, it is pointed out that some norms of the General Part of the Criminal Code of the Russian Federation are flawed in terms of falsification of official documents. The author studied the research Bunin 0.Yu., Kozachenko I.Y., comparative analysis of the provisions of the criminal code 1960 and the criminal code. The article also compares the provisions of the articles 1 , 3, 4, 5, 8, 14, 28, 32-36 The Criminal Code of the Russian Federation and relevant public relations in real life. Contradictions between the norms of the General Part of the criminal Law and the practice of application are revealed, their causes are analyzed. On what basis it is concluded that: the activities of some Russian judges and legislators has signs of forgery; there is a mismatch between the ideology of the criminal code, which borrowed from the Soviet era, and of bourgeois social relations in Russia; it is necessary to adopt a fundamentally new criminal law. The article also substantiates the expediency of introducing a preamble to the Criminal Code of the Russian Federation, which, in the author's opinion, will strengthen the criminal law as a means of persuasion and education. Options for solving problematic issues related to the presence in the General Part of the Criminal Code of the Russian Federation are considered: provisions that are ignored by law enforcement officers in connection with maintaining a vicious criminal policy; deliberately false information; unfair (discriminatory) norms.

Keywords: crime, preamble, official forgery, criminal policy, justice, judicial proceedings, court, criminal ideology, falsification of an official document, responsibility.

\author{
Митрофанов Андрей Павлович \\ Аспирант, Алтайский государственный университет \\ apm.73@yandex.ru
}

Аннотация: В настоящей статье на основании предыдущих авторских исследований указывается на неточность некоторых норм 0бщей части УК РФ В части фальсификации официальных документов. Автором изучены исследования Бунина 0.Ю., Козаченко И.Я., проведен сравнительный анализ положений УК 1960 г. и УК РФ. В статье также проведено сравнение положений статей $1,3,4,5,8,14,28,32-36$ УК РФ и соответствующих общественных отношений в реальной жизни. Выявлены противоречия между нормами Общей части уголовного закона и практикой применения, проанализированы их причины. На основании чего сделаны выводы 0 том, что: деятельность отдельных российских судей и законодателей имеет признаки служебного подлога; имеется несоответствие между идеологией УК РФ, которая заимствована из эпохи СССР, и буржуазными общественными отношениями в РФ; необходимость разработки принципиально нового уголовного закона. В статье также обосновывается целесообразность внесения в УК РФ преамбулы, что, по мнению автора, укрепит уголовный закон как средство убеждения и воспитания. Рассмотрены варианты решения проблемных вопросов, связанных с наличием в Общей части УК РФ: положений, которые игнорируются правоприменителями в связи с поддержанием ошибочной уголовной политики; заведомо ложных сведений; несправедливых (дискриминационных) норм.

Ключевые слова: преступность, преамбула, служебный подлог, уголовная политика, правосудие, судопроизводство, суд, уголовная идеология, фальсификация официального документа, ответственность.

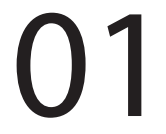

.01.1997 года вступил в силу первый уголовный закон постсоветской России - Уголовный кодекс РФ (далее по тексту - УК РФ или Кодекс) [18]. До этого момента Российская Федерация, возникшая 26.12.1991 года, применяла законодательство несуществующего государства - Уголовный кодекс РСФСР (далее по тексту - УК 1960 г.) [20]. Пять лет РФ пользовалась УК 1960 г., полагаем, что это слишком много для любого государства, которое не находится в ситуации войны, государственного переворота, революции. Следует отметить удивительное, но неслучайное историческое совпадение: большевикам после свержения законной власти тоже понадобилось пять лет, чтобы принять первый уголовный закон Советского государства - Уголовный Кодекс Р.С.Ф.С.Р. 1922 года [19].

В обоих случаях - как в 1917 г., так и в 1991 г. - мы видим возникновение нового государства в результате совершения особо тяжкого преступления. В данном случае имеет значение не столько формальная сторона действия (уголовно-наказуемое свержение законной власти), сколько сущность деяния (новые власти нарушают волеизъявление большинства граждан). В 1917 году практически все подданные РИ были крестьянами, 
которые желали получить землю в частную собственность и развиваться в русле капитализма. Большевики обманули общество, так как пообещали, но не дали гражданам ни земли, ни свободы, при этом развратили народ, уничтожив религию в попытках навязать научный коммунизм.

В 1991 году жители России проголосовали за сохранение СССР [15], то есть высказались против возникновения РФ, но верховная власть преступно нарушила волю народа. Следовательно, между РФ и Советским государством существует особая, уникальная связь - они появились вследствие преступлений, направленных против интересов общества. Давно известно, что «начало - половина всякого дела» [1, с. 349], следовательно, криминальный характер возникновения РФ неизбежно приводит к юридической порочности и нестабильности УК РФ, а также Конституции РФ [10].

Российские власти пять лет готовили свой первый уголовный закон, который должен был учитывать абсолютно новую реальность буржуазного типа. В результате революции (события 1991 года были революцией или государственным переворотом) возникли непривычные для России общественные отношения, основанные на личной заинтересованности и корыстном мотиве. Профессор В.Н. Борков правильно подметил, что многие граждане РФ преимущественно ориентируются на корысть и личный интерес [4, с. 184-185], при этом прочие интересы и мотивы стали второстепенными.

Достаточно поверхностно ознакомиться с Конституцией РФ, чтобы понять очевидный факт: Российская Федерация формально является буржуазным государством. Следовательно, УК 1960 г., ориентированный на защиту идеалов социализма, абсолютно непригоден для использования в постсоветской России, так как идеологически (принципиально) противоречит новой реальности. Уголовный закон РФ должен быть подобием западноевропейских уголовных кодексов, то есть России необходимо полностью отказаться от всех традиций советского периода: как в уголовной науке, так и в криминальном законодательстве.

Вместо этого был принят порочный УК РФ, который основан на УК 1960 г., поэтому противоречит буржуазной Конституции РФ и российской реальности. Действующий Уголовный Кодекс РФ не соответствует уголовной политике, а также уголовной идеологии постсоветской России, которые гораздо лучше защищают капиталистические общественные отношения. К сожалению, УК РФ возник как суррогат и не утратил этого качества до настоящего времени. Принципиальной (идеологической) основой Кодекса по прежнему является коммунистический УК 1960 г., из которого удалены наиболее одиозные нормы (например, ст. 154). Российский законодатель отказался использовать уго- ловно-правовой опыт капиталистических государств, но создал невиданное чудо - буржуазный УК РФ, который преимущественно использует научные и законодательные традиции эпохи социализма.

Россия является страной атеистов, так как коммунисты уничтожили религию, поэтому ученые и законодатели не знают истин, которые очевидны для благополучных государств. «Никто не вливает молодое вино в мехи ветхие. Молодое вино должно вливаться в мехи новые. Никто, пив старое вино, не захочет тотчас молодого, ибо говорит: старое лучше» [3, с. 1252]. С 1997 года и по настоящее время Россия безуспешно пытается влить молодое вино (буржуазные общественные отношения) в мехи ветхие (советские традиции уголовного закона и науки). Более того, многие ученые и законодатели продолжают ошибочно считать, что «старое вино лучше», то есть допустимо использовать научные и законодательные наработки социализма.

УК РФ был принят в состоянии непригодности к применению, при этом многочисленные поправки ухудшили Кодекс до неприемлемо низкого уровня качества. Отметим, что УК РФ является ухудшенным вариантом УК 1960 г., но еще важнее другое: советский уголовный закон никогда не имел научной основы, так как в эпоху СССР отсутствовали науки криминального цикла. Развитие уголовного права невозможно в условиях Советского государства: отсутствует криминология (уголовная социология), не используются математические методы, не изучаются реальные общественные отношения (исследуют только закон и судебную практику). В свою очередь, советская криминология не могла развиваться, так как все статистические данные о преступности были засекречены.

Тоталитарный политический строй, идеологическая монополия КПСС, отсутствие гражданского общества, полное огосударствление всех сфер жизни, отрицание какой-либо религии, навязывание псевдорелигии «научный коммунизм», юридически необразованные и зависимые от КПСС судьи - в условиях СССР невозможно развитие уголовной науки, слишком тесно связанной с политикой и властью. Кроме того, советские власти и общество слишком долго испытывали эйфорию после Победы 1945 г., поэтому идеология и наука отказывались использовать юридический опыт буржуазных государств. Напротив, Советский Союз стремился создать собственные юридические конструкции, присущие только социализму. Единственное достоинство УК 1960 г. - это социальность, то есть идеальное соответствие между социалистическими общественными отношениями и уголовным законом РСФСР. В эпоху СССР уголовный закон, уголовная политика и реальная жизнь находились в гармонии, поэтому УК 1960 г. выделяется стабильностью (минимальным количеством поправок и длительностью применения). 
Уголовный закон РФ в отличие от советского аналога не имеет ни одного достоинства: даже гармония с общественными отношениями не характерна для УК РФ, который является препятствием для общественного развития. Количество недостатков УК РФ очень большое, поэтому оставим рассмотрение пороков Особенной части УК РФ для другого исследования. Краткий анализ проблем Общей части Кодекса соответствует по объему докторской диссертации, при этом один из лучших комментариев написал адвокат, к.ю.н. О.Ю. Бунин [5]. Цель настоящей работы - рассмотреть изъяны Общей части УК РФ, обнаруженные при изучении служебных подлогов, которые совершают судьи и законодатели.

Результаты всероссийского криминологического опроса адвокатов позволяют утверждать, что российские судьи ежегодно совершают более 100 тысяч преступлений, связанных с фальсификацией протоколов судебных заседаний (далее по тексту - ПСЗ) и судебных актов: итоговых или промежуточных [12]. Такие деяния в силу специфики субъекта преступления и выполняемой государственной функции получили название судейский служебный подлог (далее по тексту - ССП), так как на практике квалифицируются только по ст. 292 УК РФ. Исследуя судейскую преступность на примере ССП - наиболее распространенного судейского преступления, автор установил, что Общая часть УК РФ обладает пороками, которые недостаточно изучены, но имеют большое значение для общественных отношений, уголовного закона, наук криминального цикла и судебной практики.

Существенной проблемой Общей части УК РФ является отсутствие преамбулы. Уголовный закон является самым важным в законодательстве, так как на основании Кодекса человек может потерять не только свободу, собственность, но и саму жизнь. Фактически уголовный закон имеет для граждан большее значение, чем Конституция РФ в силу очевидной декларативности Основного закона. В уголовных судебных актах всегда указываются нормы УК РФ и нечасто имеются ссылки на конституционные положения. Между тем, именно Конституция РФ имеет вступление, отсутствие которого в Кодексе является существенным недостатком УК РФ. Вводные положения должны подготовить читателя к уяснению последующих положений, а также кратко и понятно объяснить суть уголовного закона.

Необходимость вступительной части к закону известна с античных времен, но преамбула традиционно не используется законодателем (советским и российским). Платон пишет о том, что наилучшим изложением закона будет вариант, когда используется не только насилие, но и убеждение. Разница между законами, имеющими и не имеющими вступления, очень велика, так как закон без преамбулы - это «тираническое повеление» [14, с. 11001101]. Законодатель - в том числе российский - постоян- но забывает, что УК РФ пишется не столько для юристов, сколько для обычных граждан, которых необходимо не только наказывать, но и воспитывать при помощи уголовного закона [1, с. 199].

Уровень нравственности россиян очень низкий, что объясняется преобладанием атеизма, недостаточностью воспитания в семье, отсутствием воспитания со стороны общества и государства. В таких условиях действенность Кодекса будет низкой, так как уголовный закон создается и развивается на основании нравственных (в т.ч. - религиозных) предписаний. Самостоятельно, без помощи религии и нравственности, уголовное право работает неэффективно - об этом замечательно пишет профессор И.Я. Козаченко [7]. Конечно, преамбула к УК РФ сама по себе не решает российских проблем атеизма, необразованности, безнравственности, но законодатель обязан использовать вводные положения для самого важного из всех законов. Некоторые положения, похожие на вступление, мы видим в главе 1 УК РФ, но истинная преамбула должна предшествовать ст. 1 Кодекса, кроме того, вступление необходимо написать обычным языком, не используя юридических терминов. Необходимо создать законодательные вступления для всех кодексов - особенно важной является преамбула к самому суровому кодексу.

Серьезной проблемой является преступный характер взаимосвязанных статей 1 и 3 УК РФ. Очевидно, что законодатель внес в ч. 1 ст. 1 УК РФ заведомо ложные сведения («Уголовное законодательство ... состоит из настоящего Кодекса»). Криминальное законодательство РФ состоит не только из Кодекса - попытки оспорить данный факт являются лицемерием. Например, студентов МГУ обучают тому, что «уголовный закон является единственным законом, регламентирующим применение уголовной ответственности». Впрочем, далее по тексту преподаватели МГУ меняют своё мнение: «Некоторые законодательные акты допускают вторжение в область уголовного права» [16, с. 112]. На самом деле уголовные нормы находятся в законах (в т.ч. - в утративших силу), в документах исполнительной власти (указы Президента РФ, постановления Правительства РФ), в постановлениях Конституционного Суда РФ (далее по тексту - КС РФ) и Верховного Суда РФ (далее по тексту - ВС РФ) [9, с. 18; 8, с. 17]. Такие обстоятельства позволяют утверждать о том, что законодатель совершил криминальное деяние - законодательный служебный подлог (далее по тексту - ЗСП), то есть УК РФ является предметом преступления.

Часть вторая ст. 1 УК РФ содержит менее очевидную фальсификацию («основывается на Конституции»), для обнаружения которой требуется более сложная мыслительная деятельность. Необходимо учитывать (сравнивать между собой) не только нормы уголовного и конституционного права, но практику применения УК РФ и 
реальные общественные отношения. С одной стороны, главной челью большинства российских граждан является материальное обогащение, которое невозможно без личной заинтересованности. С другой стороны, высшие представители государственной власти чаще всего находятся в ситуации безнаказанности, поэтому обогащаются гораздо успешнее, чем все прочие граждане. Преступные доходы и безответственность высших должностных лиц порождают коррупцию, которая распространяется сверху вниз по всему обществу, практически не имеющему религиозных и нравственных ограничителей. Нормы Конституции РФ пусть не полностью, но в большей своей части соответствуют общественным отношениям капитализма. Нормы Кодекса явно противоречат буржуазной сущности государства и общества, следовательно, противоречат Конституции РФ. Уголовный закон пропитан духом социализма, так как в основании УК РФ находятся не только положения коммунистического УК 1960 г., но и традиции советской науки. Корысть и личная заинтересованность являются признаками преступлений (ст. 292 УК РФ и многие другие), что является абсурдом в обществе, основанном на корысти и личном интересе.

Ещё одним примером ЗСП является ч. 1 ст. 3 УК РФ, которая гласит: «... уголовно-правовые последствия определяются только настоящим Кодексом». Порочная норма тесно связана с ранее упомянутой ч. 1 ст. 1 УК РФ напомним, что уголовное законодательство по объему значительно превосходит Кодекс [9, с. 29]. Аналогичным образом, то есть лживо, сформулирована ч. 2 ст. 3 УК РФ: «Применение уголовного закона по аналогии не допускается». Практикующие адвокаты знают, что «аналогия в уголовном праве применяется постоянно» [5, с. 14], но ещё важнее другое: аналогия уголовного закона введена в оборот при помощи постановлений Пленума ВС РФ [9, с. 31]. Один из примеров аналогии уголовного закона это многолетнее применение ст. 292 УК РФ по отношению к судьям в силу отсутствия необходимой уголовной нормы [11].

В отличие от принципа законности, правило равенства лиц перед законом нельзя назвать полностью лживым, так как в некоторых случаях ст. 4 УК РФ соблюдается на практике. Проблему составляют противоречия с другими уголовными нормами, например, с ч. 2 ст. 57, ч. 2 ст. 59 УК РФ (половое неравенство), когда одновременно существуют два разных равенства: «среди женщин» и «среди мужчин». Ученые пытаются скрыть ошибку законодателя и замаскировать проблему: якобы, суть принципа равенства состоит в том, что каждый правонарушитель обязан «предстать перед законом и судом» [16, c. 100]. Такое толкование ошибочно: вместо принципа равенства возникает принцип неизбежности применения уголовного закона к каждому нарушителю, но никакого равенства лиц здесь нет.
Другой пример ложности ст. 4 УК РФ - это ситуация, когда в разных регионах России по-разному квалифицируются одинаковые деяния одинаковых субъектов и назначаются различные наказания. Отсутствие единообразия судебной практики, то есть фактическое наличие в РФ нескольких уголовных кодексов (региональные уголовные законы - как в США), является серьезной проблемой, которую ВС РФ не может решить с 1997 года. Указанная ситуация осложняется ужасной традицией СССР и РФ, когда отдельные сословия имеют свой собственный уголовный суд (общей юрисдикции, военный, арбитражный). Каждый сословный суд имеет свой взгляд на уголовный закон, частью которого является КоАП РФ [6]. Следовательно, арбитражный суд становится уголовным судом при рассмотрении дел, связанных с АПН.

Ещё одним аспектом отсутствия равенства лиц перед УК РФ является фактическая безнаказанность высших должностных лиц (например, судей), хотя формально указанные субъекты могут и должны привлекаться к уголовной ответственности. В доктрине преобладает мнение об отсутствии привилегии у судейского сословия, якобы, судейская неприкосновенность не нарушает принципа равенства [16, с. 101] - такая позиция противоречит здравому смыслу и реальным правоотношениям. Постсоветская Россия копирует традиции СССР (как в законах, так и в науке), но почему-то изобретает судейский иммунитет - абсолютно новый, нетрадиционный для страны институт. Никто не захотел объяснить причины этого парадокса - хотя бы на уровне теории. В реальной жизни ситуация гораздо хуже - уголовный закон практически не работает применительно к судьям, так как полностью блокируется уголовной политикой: средствами блокировки уголовного закона являются не столько нормы гл. 52 УПК РФ [17], сколько ведомственные акты и негласные (тайные) указания.

Ученые, которые оправдывают судейский иммунитет [8, с. 24], просто не знают истинного положения дел в сфере судейской преступности, кроме того, судейский иммунитет защищает не только судей (этот феномен будет рассмотрен позднее). Никто не сможет научно обосновать судейскую неприкосновенность, когда В РФ ежегодно совершается более 100 тысяч судейских преступлений в форме ССП, при этом к уголовной ответственности привлекаются не более 4 судей - в таком варианте заинтересована исполнительная власть, но не общество. Письменное заявление о совершении ССП сложно зарегистрировать, практически невозможно получить на руки постановление об отказе в возбуждении уголовного дела, тем более нереально возбудить уголовное дело. Уголовная политика судейской безнаказанности, которая является главной причиной судейской распущенности [13, с. 86], сформировалась в постсоветский период, когда из лучших побуждений (независимость судей) нанесли обществу непоправимый ущерб (криминализация судейского сообщества) [2, с. 89]. В период с 1917 г. до 2002 г. 
судейский иммунитет отсутствовал, что позволяло эффективно бороться с судейской преступностью.

Следующая проблема - недейственность (иллюзорность) принципа вины (ст. 5 УК РФ) получит краткий комментарий, так как ранее рассматривалась в другой публикации [11]. Когда служебный подлог совершает представитель судебной власти, тогда вина предполагается в силу юридической образованности указанного субъекта преступления. Когда служебный подлог совершает представитель исполнительной (карательной) власти (далее по тексту - КСП), тогда чаще всего применяется объективное вменение в силу уголовно-правового невежества субъекта преступления. Следует отметить, что в ситуации КСП одновременно нарушается ч. 1 ст. 28 УК РФ: "Личо ... не осознавало и ... не могло осознавать общественной опасности своих действий».

Проблема постоянного нарушения ст. 8 УК РФ «основанием ... ответственности является совершение деяния, содержащего все признаки состава преступления, предусмотренного ... Кодексом» - имеет несколько проявлений с точки зрения служебного подлога. В ситуации КСП отсутствует признак вины, в ситуации ССП, напротив, вина налицо, но все прочие признаки деяния противоречат сущности ст. 292 УК РФ, поэтому квалификация ССП по указанной статье - это аналогия уголовного закона [11].

Серьезным недостатком уголовного закона является формулировка статьи 14 УК РФ, причем корни проблемы традиционно находятся в эпохе СССР (смотри ст. 7 УК 1960 г.). На первый взгляд, 4. 2 cm. 14 УК РФ имеет избыточный характер, так как в ч. 1 имеется достаточное описание общественной опасности. Малозначительность деяния (оценочная категория) используется в судебной практике крайне редко, только на уровне ВС РФ [5, с. 30-34], но этот факт вовсе не означает, что ч. 2 ст. 14 УК РФ не работает за пределами ВС РФ. Напротив, уголовная политика РФ применительно к судейским преступлениям фактически основана на малозначительности таких деяний. Государственные органы отказываются регистрировать и проверять письменные заявления о совершении ССП, а также привлекать судей к уголовной ответственности, так как безотказно действует негласная презумпиия малозначительности судейского служебного подлога, при этом малозначительность не применяется по отношению к деяниям врача или педагога (при совершении КСП).

От малозначительности переходим к соучастию (ст. ст. 32-36 УК РФ), которое наблюдается в большинстве судейских криминальных деяний. Основную часть судейской преступности в РФ составляет ССП (более 100 тысяч преступлений ежегодно), причем судейский служебный подлог чаще всего совершается в форме фальсификации ПСЗ. Протокол подписывают двое: судья и секретарь судебного заседания (далее по тексту - Секретарь) или помощник судьи (далее по тексту - Помощник), следовательно, в случае умышленной фальсификации ПСЗ необходимо привлекать к уголовной ответственности, используя нормы гл. 7 УК РФ. На практике преступные действия Секретаря или Помощника не получают никакой оценки, хотя судьи иногда привлекаются по ст. 292 УК РФ за фальсификацию ПСЗ. Иными словами, характерной чертой судейской преступности является соучастие, при этом групповой признак (судья + Секретарь или Помощник) не применяется.

Более того, письменные заявления о совершении фальсификации ПСЗ силами Секретаря или Помощника чаме всего не приводят к уголовному преследованию, хотя указанные лица не обладают иммунитетом в рамках гл. 52 УПК РФ. Причина парадокса понятна: в случае преследования Секретаря или Помощника за фальсификацию ПСЗ неизбежно возникает вопрос о виновности судьи - соучастника преступления. Следует отметить, что соучастие часто наблюдается, когда итоговый судебный акт фальсифицируется при коллегиальном рассмотрении дела, но этот вариант вовсе недоступен для уголовного преследования в силу уголовной политики РФ.

Указанная политика является причиной фактической безнаказанности судейского сообщества, однако изредка криминальные судьи привлекаются к уголовной ответственности. Если преследование судьи доходит до назначения наказания, тогда проявляются недейственность и (или) порочность некоторых положений гл. 10 УК РФ. Например, не применяются в отношении судей пункты б) («наступление тяжких последствий»), в) («совершение преступления в составе группы лиц») ч. 1 ст. 63 УК РФ, хотя судейская преступность чаще всего обладает такими качествами.

Кроме того, ССП нередко совершается «с иелью скрыть другое преступление или облегчить его совершение», но пункт е.1) ч. 1 ст. 63 УК РФ не применяется, при этом скрываемое преступление игнорируется. В реальной жизни (но не в приговорах) часто наблюдается ситуация, когда суд не разъясняет процессуальные права для участников судебного разбирательства (преступление № 1) и после этого фальсифицирует ПСЗ: якобы, процессуальные права разъяснялись (преступление № 2). Далее отметим, что органы уголовной юстиции незаконно отказываются применять к судейским преступлениям пункт м) ч.1 ст. 63 УК РФ («... с использованием доверия, оказанного виновному в силу его служебного положения). Возможно, проблема объясняется отсутствием доверия граждан к судебной системе: в 2020 году 70\% россиян не доверяло российским судам [12].

Применительно к судейским преступлениям внимания заслуживает пункт о) - «совершение ... преступления сотрудником органа внутренних дел» - ч. 1 ст. 63 УК РФ. 
Порочная норма противоречит логике и здравому смыслу, а также нарушает требования Конституции РФ, но данный факт зачастую игнорируется в науке [9, с. 219; 8 , с. $284 ; 16$, с. 641$]$. Полностью прав О.Ю. Бунин, когда утверждает о несправедливости выделения сотрудника органа внутренних дел (далее по тексту - СОВД) из совокупности всех представителей правоохранительных органов [5, с. 119]. Общеизвестно, что умышленные преступления при исполнении государственных функций совершают следователи, прокуроры и судьи. На фоне указанных профессиональных сословий любой СОВД будет отличаться наименьшим объемом властных полномочий, самым низким уровнем юридической образованности и морально-волевых качеств. СОВД является наиболее уязвимым представителем правоохранительных органов и по этой причине подвергается дискриминации в уголовном законе.

Судьи КС РФ игнорируют очевидное противоречие между ст. 19 Конституции РФ и вышеуказанной нормой УК РФ: в определении от 08.12.2011 года N 1623-О-О отмечается, что на СОВД возложена исключительная по своему объему и характеру - даже в сравнении с сотрудниками иных правоохранительных органов - ответственность. Данное утверждение является заведомо ложными сведениями, внесенными в официальный документ, то есть судьи КС РФ совершили ССП. В ложности выводов КС РФ можно убедиться, если сравнить между собой статусы (судьи и СОВД), а также нормативные требования к нравственным качествам и уровню юридической образованности. С точки зрения объема и характера служебных полномочий наименее властный судья (мировой) должен нести более серьезную ответственность, чем любой СОВД. Можно объяснить, но нельзя оправдать ложь КС РФ, который является частью судебной системы. Давно известно, что человек видит соринку в чужом глазу (СОВД) и не замечает в собственном (судейском). Библейская истина применима к судьям КС РФ: «Лицемер! Вынь прежде бревно из твоего глаза, и тогда увидишь, как вынуть сучок из глаза брата твоего» [3, с. 1254].

Итак, в заключение работы сформулируем выводы и рекомендации. Первым выводом будет невозможность исправления Общей части Кодекса. Необходимо принятие нового уголовного закона, основанного на буржуазной идеологии. Действующий Кодекс противоречит буржуазным общественным отношениям, так как идеологически основан на УК 1960 г. В современный уголовный закон перешли недостатки эпохи социализма: из криминального законодательства, из наук криминального цикла, из практики применения. При этом в Кодексе отсутствует социальность, которая была единственным достоинством УК 1960 г. Этот факт является причиной многочисленных поправок, которые к уголовно-правовым изъянам (из советского прошлого) добавили новые язвы (постсоветской России). Новый уголовный закон необходимо создавать, максимально игнорируя национальные традиции законодательства и науки, так как указанные традиции сформировались в эпоху социалистических общественных отношений.

Второй вывод: законодатель внес в некоторые нормы Общей части УК РФ заведомо ложные сведения, что является преступным деянием. Законодателя нельзя привлечь к уголовной ответственности за совершение 3СП, но для законодателя существует ответственность более серьезная, чем уголовная: лживость и лицемерие верховной власти неизбежно приводят к саморазрушению государства - именно так разрушился СССР. По этой причине необходимо убрать из Кодекса ложные сведения, изложенные, например, в ст. 1 и ст. 3 УК РФ, чтобы уголовный закон соответствовал реальным общественным отношениям.

Tретий вывод: отсутствие системности и эффективности уголовного закона - нормы Общей части УК РФ противоречат нормам Особенной части УК РФ и постоянно нарушаются правоприменителем. С одной стороны, причиной проблемы является общая порочность всего Кодекса целиком, то есть несоответствие между буржуазными общественными отношениями и нормами УК РФ. С другой стороны, требования ст.ст. 4, 5, $8,14,28,32-36,63$ нарушаются в силу порочной уголовной политики, которая гораздо опаснее для общества, чем коммунистический по духу Кодекс. В основании уголовной политики находятся не принципы УК РФ и УПК РФ, но негласный принцип практической целесообразности. Нельзя исправить порочное применение Кодекса без изменения уголовной политики - такое изменение в настоящее время невозможно по причине несменяемости верховной власти.

Четвертый вывод: в Кодекс необходимо добавить преамбулу. Вступление к главному закону уголовных правоотношений нужно написать понятным (литературным) языком, поэтому авторами преамбулы должны стать люди, получившие не только юридическое образование. Возможно, преамбула к уголовному закону покажется странной для юристов - более того, нелогично писать вступление для порочного Кодекса, который необходимо отменять. Тем не менее, предложение о преамбуле будет иметь ценность для нового уголовного закона, который рано или поздно появится в России. Существует альтернативный вариант - дождаться, когда преамбула получит распространение в уголовных законах других государств, после чего воспользоваться зарубежным опытом. Гораздо лучше - быть первым в написании вступления, главной мыслью которого будет вечная мудрость: «Как хотите, чтобы с вами поступали люди, так поступайте и вы с ними, ибо в этом закон» [3, с. 1193]. 


\section{ЛИТЕРАТУРА}

1. Аристотель. Политика. - Москва: РИПОЛ классик, 2020. - 528 с.

2. Бекариа Ч. 0 преступлениях и наказаниях. - Москва: Стелс, 1995. - 304 с.

3. Библия. - Москва: Сибирская Благозвонница, 2020. - 1488 с.

4. Борков В.Н. Преступления против осуществления государственных функций, совершаемые должностными лицами. - Москва: Юрлитинформ, 2016. - 344 с.

5. Бунин 0.Ю. Научно-критический комментарий к Общей части УК РФ. - Москва: Филин, 2017. - 312 с.

6. Кодекс Российской Федерации об административных правонарушениях от 30.12.2001 N 195-Ф3 (ред. от 30.12.2020) // [Электронный ресурс]: СПС КонсультантПлюс.

7. К Козаченко И.Я. Закон идеологии и идеология уголовного закона // Российский юридический журнал. 2008. N 4. - С. 23-27.

8. Комментарий к Уголовному кодексу Российской Федерации (научно-практический) / под ред. А.И. Чучаева. - Москва: Проспект, 2019. - 1536 с.

9. Комментарий к Уголовному кодексу Российской Федерации (научно-практический) / под ред. О.С. Капинус. - Москва: Проспект, 2018. - 1376 с.

10. Конституция Российской Федерации (принята всенародным голосованием 12.12.1993 с изменениями, одобренными в ходе общероссийского голосования 01.07.2020) // [Электронный ресурс]: СПС КонсультантПлюс.

11. Митрофанов А.П. Служебный подлог, совершаемый российскими судьями: незаконность квалификации по статье 292 Уголовного кодекса РФ // Юридическая наука. 2020. N 12. - С. 84-90.

12. Митрофанов А.П. Служебный подлог, совершаемый российскими судьями: постановка проблемы // Право и практика. 2020. N 4. - С. 159-164.

13. Монтескье Ш. 0 духе законов. - Москва: РИПОЛ классик, 2018. - 690 с.

14. Платон. Полное собрание сочинений в одном томе. - Москва : АЛЬФА-КНИГА, 2020. - 1311 с.

15. Постановление ВС СССР от 16.01.1991 N 1910-1 «0б организации и мерах по обеспечению проведения референдума СССР по вопросу о сохранении Союза Советских Социалистических Республик» // [Электронный ресурс]: СПС КонсультантПлюс.

16. Уголовное право Российской Федерации. Общая часть / под ред. В.С. Комиссарова [и др.]. - Москва : Статут, 2016. - 879 с.

17. Уголовно-процессуальный кодекс Российской Федерации от 18.12.2001 N 174-Ф3 (ред. 0т 19.12.2020) // [Электронный ресурс]: СПС КонсультантПлюс.

18. Уголовный кодекс Российской Федерации от 13.06.1996 N 63-ФЗ (ред. от 30.12.2020) // [Электронный ресурс]: СПС КонсультантПлюс.

19. Уголовный Кодекс Р.С.Ф.С.Р. от 01.06.1922 (ред. от 01.06.1922) // [Электронный ресурс]: СПС КонсультантПлюс.

20. Уголовный кодекс РСФСР от 27.10.1960 (ред. от 27.10.1960) // [Электронный ресурс]: СПС КонсультантПлюс.

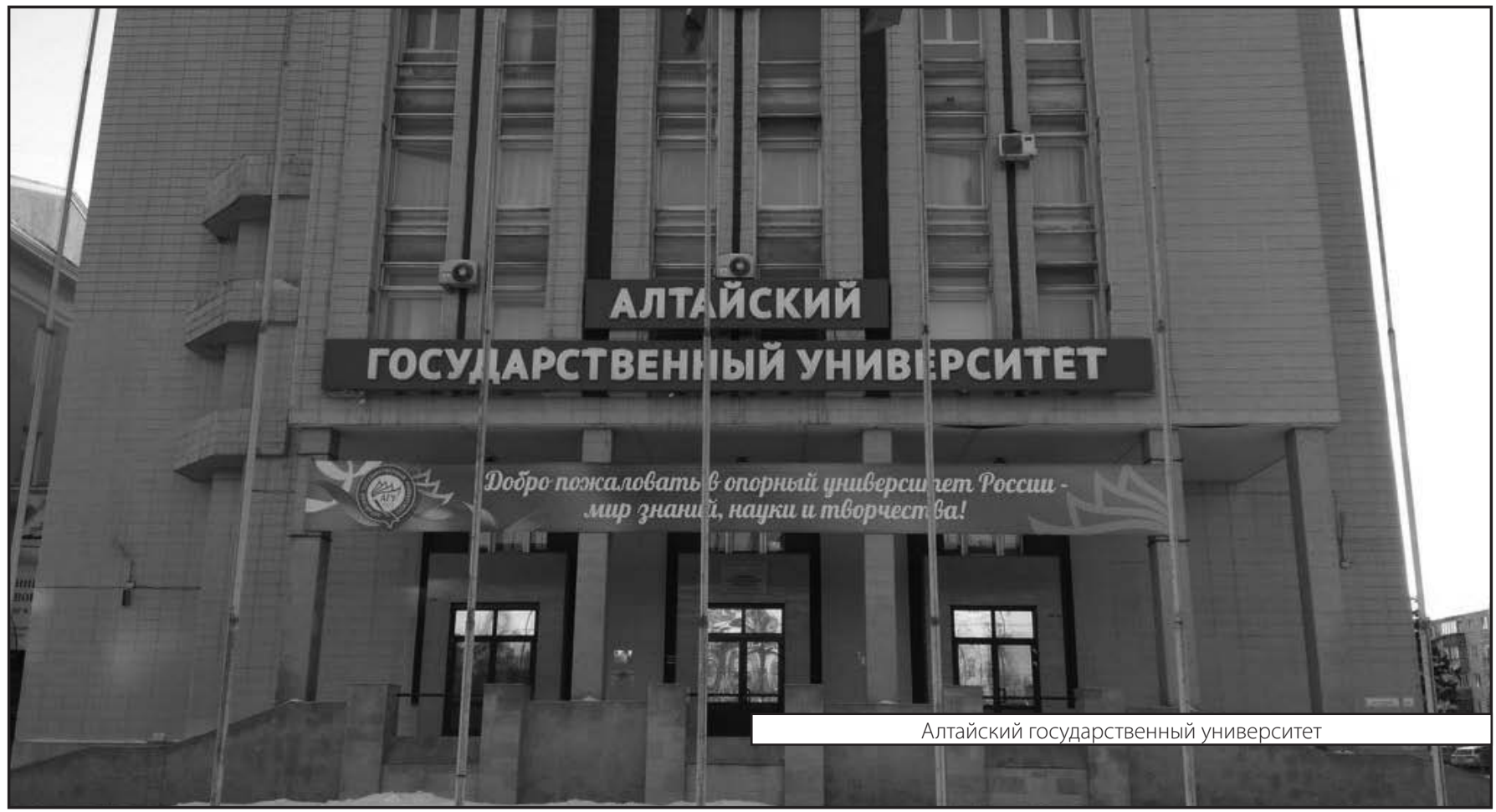

